\author{
Maciej Dębski \\ https://orcid.org/0000-0002-8339-5073 \\ Małgorzata Borkowska-Niszczota \\ https://orcid.org/0000-0003-2169-6062 \\ Społeczna Akademia Nauk \\ Wydział Nauk o Zarządzaniu i Bezpieczeństwie \\ Katedra Marketingu i Turystyki \\ mdebski@san.edu.pl,mbniszczota@san.edu.pl
}

\title{
EKOLOGICZNE ZACHOWANIA KONSUMPCYJNE I STOSUNEK DO PROEKOLOGICZNYCH DZIAŁAŃ W OBIEKTACH NOCLEGOWYCH PRZEDSTAWICIELI POKOLENIA Z
}

\begin{abstract}
Abstrakt: Artykuł ma charakter empiryczny. Jest oparty na wynikach badań ankietowych. Głównym celem opracowania było ukazanie ekologicznych zachowań i wyborów konsumpcyjnych osób należących do pokolenia Z oraz ich stosunku do rozwiązań proekologicznych wdrażanych $\mathrm{w}$ ramach polityki ekologicznej przedsiębiorstw turystycznych świadczących usługi noclegowe. Autorzy artykułu próbowali również określić, czy wdrażane rozwiązania mogą zachęcić młodych ludzi do wyboru przyjaznych dla środowiska obiektów świadczących usługi noclegowe i tym samym być źródłem przewagi konkurencyjnej. Opis wyników badań własnych został poprzedzony przeglądem dotychczasowych studiów poświęconych analizowanym zagadnieniom oraz podstaw teoretycznych zrównoważonej konsumpcji. W tym celu wykorzystano metodę badań literaturowych. Analiza wyników pokazuje, że osoby zaliczane do pokolenie $\mathrm{Z}$ w większości starają się ograniczać swój negatywny wpływ na środowisko i stosować zasady ekologii w praktyce. Popierają zachowania proekologiczne, stąd na co dzień podejmują działania na rzecz ochrony środowiska, ale przeważnie takie, które dostarczają im korzyści finansowych oraz zdrowotnych. Młodzi deklarują - choć w różnym stopniu - akceptację większości rozwiązań proekologicznych wprowadzanych w bazie noclegowej. Za swoje zaangażowanie w praktykę proekologiczną w obiektach turystycznych oczekują jednak profitów finansowych. Mimo to lepiej oceniają obiekty wdrażające proekologiczne rozwiązania i chętniej by się w nich zatrzymali.
\end{abstract}

Słowa kluczowe: zrównoważona konsumpcja, pokolenie Z, proekologiczne rozwiązania, turystyka, obiekty noclegowe.

\section{WSTĘP}

Młodzi ludzie są ważną częścią rynku turystycznego. Jako konsumenci charakteryzują się relatywnie dużą ilością wolnego czasu, mobilnością i ciekawością świata. Ponadto chcą poznawać nowe kultury, być blisko natury i lokalnej społeczności (Buffa, 2015). Wartość rynku turystycznego osób młodych w 2009 r. szacowano na blisko 190 mld dolarów, a w 2014 r. - na 286 mld. Prognozuje się, że w $2020 \mathrm{r}$. wyniesie on ponad $400 \mathrm{mld}$ dolarów (Richards, 2016).

Według Anderson i Sharpa (2010) osoby młode mają mniej niż 30 lat. Należą one do pokoleń Y i Z. Autorzy skoncentrowali się na drugiej z badanych grup, do której zalicza się osoby urodzone pomiędzy 1995 a 2010 r. (Lazányi, Bilan, 2017; Vallone i in., 2016), a więc mające obecnie 10-25 lat. Istnieje deficyt badań opisujących ludzi z tego przedziału wiekowego, chociażby ze względu na fakt, że wielu z nich to osoby niepełnoletnie (Sauthgate, 2017).
Wskazuje się, że młodzi ludzie są niezależni (Desai, Lele, 2017), spodziewają się szybkiego i pełnego dostępu do wiedzy i uzyskiwania natychmiastowych odpowiedzi na zadawane pytania (Opris, Cenusa, 2017). Często wykorzystują Internet i narzędzia z nim związane podczas konsumpcji turystycznej, co jest przedmiotem licznych analiz (Hamed, 2017; Ip, Lee, Law, 2012; Nemec Rudež, Vodeb, 2015).

Pokolenie Y (tzw. milenialsi) najczęściej postrzegane jest jako zorientowane ekologicznie (green oriented), natomiast generacja $\mathrm{Z}$ (postmilenialsi) - jako zorientowana społecznie. Oznacza to, że jej przedstawiciele są zaangażowani w wiele problemów współczesnego świata. Wskazuje się, że osoby należące do pokolenia $\mathrm{Z}$ biorą udział w akcjach społeczno-politycznych w mediach społecznościowych, wspierają słabszych, wykluczonych. Oprócz znajomości kwestii społecznych 
orientują się także w tematyce związanej z ekologią i ochroną środowiska. Zależy im na jakości i wytrzymałości produktów, ale też zwracają uwagę na kwestie ekologiczne (ekogeneracja Z).

Korzyści ekologiczne powinny być jedną z przyczyn wyboru produktów. Zrozumienie motywów zakupowych i źródeł satysfakcji klientów jest kluczowe dla efektywnej sprzedaży, opierającej się na tworzeniu wartości. Dlatego należałoby przeprowadzić badania dotyczące grup determinujących popyt na rynku turystycznym. Jedną z nich są właśnie osoby młode.

Zgodnie z założeniami Agendy na rzecz zrównoważonego rozwoju 2030 (Przekształcamy nasz świat..., 2020) społeczności powinny być odpowiedzialne za realizację celów związanych ze zrównoważoną konsumpcją. Jednym z jej rodzajów jest ekologiczna konsumpcja, która powinna dotyczyć zachowań i wyborów turystów w trakcie podróży oraz w miejscu świadczenia usług turystycznych. Patrząc z tej perspektywy, za potrzebne należy uznać badanie ukierunkowane na rozpoznanie proekologicznych postaw młodych ludzi (jako konsumentów produktów turystycznych) oraz ich stosunku do rozwiązań wdrażanych w tym zakresie w obiektach noclegowych w celu uzyskania przewagi konkurencyjnej.

W związku z powyższym głównym celem opracowania było ukazanie ekologicznych zachowań i wyborów konsumpcyjnych przedstawicieli pokolenia Z oraz ich stosunku do rozwiązań proekologicznych wdrażanych w ramach polityki ekologicznej przedsiębiorstw turystycznych świadczących usługi noclegowe. Jednocześnie próbowano znaleźć odpowiedź na pytanie, czy działania na rzecz ochrony środowiska mogą zachęcić młode pokolenie do wyboru przyjaznych dla środowiska obiektów świadczących usługi noclegowe i tym samym być źródłem przewagi konkurencyjnej tych obiektów. W konsekwencji postawiono hipotezę głosząca, że polityka ekologiczna i przestrzeganie jej zasad mogą stanowić źródło przewagi przedsiębiorstwa oferującego usługi noclegowe.

\section{ANALIZA LITERATURY}

Koncepcja zrównoważonego rozwoju stanowi istotne zagadnienie w turystyce (Tzschentke, Kirk, Lynch, 2004). Według UNWTO, uprawiając turystykę zrównoważona, należy:

- optymalnie korzystać z zasobów środowiska, które są kluczowym elementem jej rozwoju, i przyczyniać się do zachowania dziedzictwa naturalnego i różnorodności biologicznej;

- szanować autentyczność społeczności obszarów recepcyjnych, chronić ich dziedzictwo kulturowe i tradycyjne wartości oraz promować międzykulturowe zrozumienie i tolerancję;

- zabezpieczać długotrwałe funkcjonowanie gospodarki, zapewniając korzyści społeczno-gospodarcze wszystkim interesariuszom (Nowacki i in., 2017; UNWTO, 2017).

Istotę jej implementacji stanowią m.in. dwie płaszczyzny działań - kształtowanie zrównoważonej konsumpcji turystycznej oraz funkcjonowanie turystycznych podmiotów gospodarczych zgodnie z zasadami zrównoważonego rozwoju (Burzyński, Abram, 2011). Wdrożenie zrównoważonej konsumpcji jest równoznaczne z przyjęciem odpowiedzialności przez nabywców za dokonywanie zakupów w sposób etyczny w celu zmniejszenia negatywnego wpływu na środowisko (Bruska, 2016; Evans, 2011), co ma zapewnić godne życie dla każdego w granicach zasobności Ziemi (Bruska, 2016; Lorek, Fuchs, 2013; Lorek, Spangenberg, 2014). W literaturze spotyka się dwa typy zrównoważonej konsumpcji, tj. przyjazną ekologicznie, „zieloną”, oraz społecznie odpowiedzialną (Bruska, 2016). Pierwsza oznacza wykorzystywanie dóbr i usług zaspokajających podstawowe potrzeby ludzi i poprawiających jakość ich życia, a jednoczenie minimalizujących zużycie zasobów naturalnych i toksycznych materiałów oraz wpływających na zmniejszenie ilości produkowanych odpadów (Ryszawska-Grzeszczak, 2007). Ekologiczne zachowania związane są z konsumpcją produktów ekologicznych, wzrostem wydatków na żywność ekologiczna, oszczędnym wykorzystaniem dóbr konsumpcyjnych, kupowaniem towarów, które nie powodują powstawania dużej ilości odpadów, segregowaniem śmieci i recyklingiem. Wykreowanie konsumenta proekologicznego stanowi niezbędny warunek zaistnienia rynku produktów nieszkodliwych dla środowiska (Kryk, 2011).

W związku z potrzebą realizacji celów ekologicznych w ramach turystyki zrównoważonej wpływ rozwoju turystyki na środowisko jest istotnym tematem analiz (Berezan, Millar, Raab, 2014). Zwraca się uwagę, że zrównoważone projektowanie (sustainable design) jest kluczowe dla destynacji i nadążania za współczesnymi tendencjami rynkowymi. Podkreśla się, że koncepcja zrównoważonego rozwoju w turystyce najbardziej uwidacznia się w sektorze usług noclegowych (Mousavi, Hoşkara, Woosnam, 2017). Wiąże się to z jego dynamicznym rozwojem, który przekłada się na silne oddziaływanie na środowisko (da Rosa, Silva, 2017). Realizacja koncepcji zrównoważonego rozwoju na poziomie przedsiębiorstwa świadczącego usługi noclegowe odbywa się poprzez implementację zasad społecznej odpowiedzialności biznesu (Corporate Social Responsibility - CSR) i podejmowane działania proekologiczne, prospołeczne, mające na celu dobro pracowników oraz gości. Inicjatywy na rzecz podnoszenia świadomości ekologicznej klientów korzystających z tych usług 
mogą z jednej strony powodować wzrost skłonności firm do postawy społecznie odpowiedzialnej, z drugiej zaś - prowadzić do wzrostu zainteresowania dobrami o wysokich parametrach ekologicznych (Kryk, 2011).

Jednym $\mathrm{z}$ aspektów zrównoważonego rozwoju są działania mające na celu ochronę środowiska, która jest kluczowa dla rozwoju turystyki w wielu regionach. Z tego powodu ekologię traktuje się priorytetowo w działalności wielu podmiotów turystycznych, w tym w obiektów bazy noclegowej. Znajduje to odzwierciedlenie w systemie zarządzania i strategiach rozwoju, w których dąży się do opracowania i/lub poprawy polityki środowiskowej, podejmowania działań mających na celu zminimalizowanie ujemnego wpływu obiektu na środowisko, np. przez wdrażanie programów oszczędzania wody czy energii. Są to zwykle inicjatywy dobrowolne, wynikające z potrzeby rozwoju i dostosowania się do trendów i standardów europejskich i światowych w gospodarce turystycznej (Borkowska-Niszczota, 2011).

W literaturze zaznacza się, że obiekty noclegowe są coraz bardziej ukierunkowane na dbanie o środowisko, również wskutek wprowadzanych regulacji prawnych (Berezan, Millar, Raab, 2014). Jak podkreślano, istotne dla stymulowania pewnych zachowań wśród przedsiębiorców, czy też władz lokalnych są oczekiwania konsumentów. Wywierana przez nich presja stanowi katalizator działań przedsiębiorców (da Rosa, Silva, 2017). Zwraca się uwagę, że przestrzeganie zasad zrównoważonego rozwoju podnosi jakość produktu, co wpływa na satysfakcję klientów (Edgell, 2006). Przedsiębiorcy budują swoją markę, opierając się na skojarzeniu z ekologią (Kapera, Wszendybył-Skulska, 2017).

Przemysł gościnny (hospitality industry) w zakresie ochrony środowiska jest kluczowym elementem turystyki (Erdogan, Baris, 2007). Jak podają eksperci, oddziaływanie hoteli na środowisko w ok. 75\% było bezpośrednio powiązane $\mathrm{z}$ nadmierną konsumpcją (Bohdanowicz, 2006). Postawa klientów obiektów noclegowych, zrównoważona konsumpcja oraz akceptacja wdrażanych rozwiązań mogą zatem ograniczyć ten negatywny wpływ. W związku z tym ważne jest włączanie klientów w proekologiczne działania obiektów poprzez możliwość rezygnacji z codziennej wymiany pościeli i ręczników, stosowanie szarego papieru toaletowego i dozowników na mydło, wprowadzenie kart zbliżeniowych umożliwiających dopływ energii, wykorzystywanie niskiej mocy oświetlenia na terenie obiektu, zaopatrzenie siłowni w urządzenia do ćwiczeń wspomagające produkcję energii elektrycznej, selektywną zbiórkę odpadów czy edukację w zakresie odpowiedzialnych zachowań. W celu większego zaangażowania konsumentów w ochronę środowiska już dzisiaj stosowane są takie rozwiązania, jak np.: darmowy posiłek dla gości, którzy korzystając z rowerku treningowego podłączonego do generatorów, wyprodukują przynajmniej 10 watogodzin energii elektrycznej (Hotel Crowne Plaza Copenhagen Towers w Danii), transport busem do okolicznych wyciągów zawarty w cenie za pobyt (hotel Nad Przełomem), kupony na przekąski i napoje w zamian za zrzeczenie się codziennego serwisu hotelowego (hotele Sheraton) (Borkowska-Niszczota, 2011, 2015).

Można się zastanawiać, w jakim stopniu zasady zrównoważonego rozwoju są rzeczywiście wprowadzane. Zapewne częstotliwość wdrażania tego typu rozwiązań wzrośnie, jeśli płynące z nich korzyści będą większe niż koszty ich wprowadzenia. Jak podkreśla Ryan (2002), podejmowanie niektórych działań proekologicznych może przynieść milionowe oszczędności. Managerowie obiektów dostrzegają te możliwości i starają się optymalizować zużycie wody i energii, czy też ograniczać ilość śmieci (Mousavi, Hoşkara, Woosman, 2017). Nowe metody zarządzania, wdrażane w obiektach noclegowych, dają możliwość uzyskania przewagi konkurencyjnej (Borkowska-Niszczota, 2011). Stwarza to możliwość wyróżnienia się na rynku (Beccera, Santalo, Silva, 2013) i w konsekwencji podniesienia wartości marki. Część przedsiębiorców nie wykorzystuje jednak tej szansy, ponieważ nie dostrzega korzyści płynących z omawianych działań (Kang, Stein, Heo, Lee, 2012).

Inicjatywy związane z osiąganiem przewagi konkurencyjnej w wyniku zachowań proekologicznych różnią się w zależności od jakości usług oferowanych w obiekcie (Ge, Chen, Chen, 2018). Działania proekologiczne mogą być narzędziem pozyskiwania lojalności klientów. Inne zalety tego typu przedsięwzięć to: gwarancja dobrych stosunków z lokalnymi interesariuszami, poprawa wizerunku przedsiębiorstwa (również na tle konkurencji), zgodność z przepisami prawa (Prochorowicz, 2015). Wizerunek obiektu, w którym dba się o środowisko, dodatnio wpływa na kreowanie marketingu szeptanego, gotowość do zapłacenia więcej czy chęć powrotu w to samo miejsce (Han, Hsu, Lee, 2009; Kelly, Haider, Williams, Englund, 2007; Lee, Hsu, Han, Kim, 2010). Nie można jednak zakładać, że wszyscy klienci będą bezkrytycznie akceptować politykę ekologiczną hoteli. Wprawdzie istnieje grupa konsumentów oczekujących wprowadzania rozwiązań proekologicznych w hotelach i gotowych za to zapłacić, jednak nie wiadomo, czy jest ona na tyle liczna, by można było uznać za zasadne przeprowadzenie inwestycji prośrodowiskowych, skutkujących podwyższeniem cen. Tym bardziej że są także konsumenci, którzy nie chcą płacić więcej za proekologiczny nocleg, nawet jeśli mają świadomość znaczenia tego typu inicjatyw (Manaktola, Jauhari, 2007). Ponadto deklaracje nie muszą się przekładać na realne działania. W badaniu przeprowadzonym przez Berezana, Millar i Raab (2014) przeszło 80\% respondentów deklarowało gotowość płacenia więcej za rozwiązania proekologiczne. $W$ tej samej grupie ponad $40 \%$ ankietowanych uznało, że do zachowań związanych z ochroną środowiska 
konsumentów najbardziej motywowałaby zniżka ceny za nocleg. Na gotowość konsumentów do płacenia więcej za noclegi w obiektach, w których przestrzega się zasad proekologicznych, wskazują także inne analizy (Kang, Stein, Heo, Lee, 2012; Kostakis, Sardianou, 2012; Millar, Baloglu, 2011). W badaniu, które przeprowadzili Han, Hsu, Lee i Sheu (2011), 90\% respondentów wskazało, że wolałoby nocować w hotelu, w którym promuje się ekologię. Robinot i Giannelloni (2010) potwierdzili hipotezę, że inicjatywy na rzecz ochrony środowiska mogą być uznawane za podstawowy atrybut hotelu. Ponadto ograniczenia związane z obniżeniem komfortu gościa były postrzegane jako bariera pewnych zachowań (Baker, Davis, Weaver, 2014; Han, Chan, 2013). Co więcej, Baker, Davies i Weaver (2014) wskazuja, że konsumenci chętniej przyjmują postawę proekologiczną w domu niż w hotelu.

Z badań naukowych wynika, że goście pozytywnie oceniają obiekty proekologiczne (Chen, Tung, 2014; Gao, Mattila, 2014), jednak zauważalne są różnice w podejściu do ekologii w zależności od płci (Han, Hsu, Lee, Sheu, 2011) i wieku (Sidali, Huber, Schamel, 2017). Z kolei Millar, Mayer i Baloglu (2012) analizowali, jakie oczekiwania względem ekologii i podejście do kwestii z nią związanych mają turyści biznesowi i uprawiający turystykę wypoczynkową (leisure tourists), jednak nie odnotowali znaczących różnic pomiędzy tymi grupami.

Innym badanym aspektem w sferze zrównoważonego rozwoju sektora hotelarskiego jest wpływ pracowników na prowadzenie działań proekologicznych (Chan, Hawkins, 2010). Kolejnym ważnym obszarem badań jest analiza determinant wprowadzania rozwiązań proekologicznych. Gil, Jimenez i Lorente (2001) wskazywali ponadto na zależność pomiędzy tym procesem a czasem funkcjonowania obiektu, jego wielkością przynależnością do sieci, czy też wynikiem finansowym. Interesującym przedmiotem analiz może być również kooperacja, zwłaszcza międzynarodowa, ukierunkowana na zwiększenie kompetencji, realizację nowych pomysłów i w efekcie wdrożenie rozwiązań proekologicznych (Ge, Chen, Chen, 2018).

Również w Polsce prowadzone są badania nad działaniami proekologicznymi w hotelach. W wyniku tych studiów uwypukla się brak zrozumienia idei ekorozwoju przez konsumentów (Kapera, Wszendybył-Skulska, 2017). Do najważniejszych czynników determinujących wybór hotelu należą: jakość, lokalizacja i cena (wszystkie miały ok. 60\% wskazań). Znacznie mniej respondentów (32\%) zwróciło uwagę na znaczenie działań proekologicznych w procesie decyzyjnym (Kapera, Wszendybył-Skulska, 2017). Liczby tej nie można jednak uznać za niską. Świadomość ekologiczna jest postrzegana jako istotny czynnik wtórny, który może okazać się kluczowy, jeśli ocena obiektów wybranych przez konsumenta na podstawie trzech wymienionych wcześniej kryteriów będzie porównywalna. Na podobne determinanty wyboru zwraca uwagę Kasim (2004), która dochodzi do konkluzji, że inwestycje ukierunkowane na ekologię są stratą zasobów.

Można wskazać kilka grup czynników warunkujących wprowadzenie rozwiązań proekologicznych w obiektach noclegowych. Są to: przepisy prawa, korzyści materialne, oczekiwania klientów i wywierana przez nich presja. Analizy przedstawione w niniejszym opracowaniu dotyczą ostatniego z wymienionych motywów. To właśnie rosnąca świadomość ekologiczna i związany z nią nacisk kładziony na ochronę środowiska doprowadziły do rozwoju koncepcji przydatnych do analizy wpływu obiektów noclegowych na otoczenie (Liang, 2013). Jednym z narzędzi wykorzystywanych do syntetycznej oceny tego wpływu jest system Green Key Eco-Rating Program (Pawłowski, 2016). Konsumenci bardziej niż kiedyś zwracają uwagę na podmioty i produkty wiążące się z dbałością o ekologię, co może być również użyteczne w procesie ich promowania (D'Souza, Taghian, 2005).

Troska o środowisko naturalne jest bardzo ważna również dla osób należących do pokolenia Z, dlatego ograniczają one swój negatywny wpływ na otoczenie i chętnie angażują się w inicjatywy proekologiczne. Jest to pierwsze pokolenie świadome zmian ekologicznych i negatywnego wpływu ludzi na naszą planetę (ekogeneracja Z).

Potwierdzeniem zaprezentowanych wniosków są także wyniki badań Hana, Kima i Kiatkawsina (2017), które mogą przełamywać pewien stereotyp młodego człowieka. Z jednej strony wyniki tych studiów przemawiają za hipoteza, że młodzież dba o środowisko i chętnie podejmuje działania proekologiczne. Z drugiej strony istnieją także publikacje ukazujące inne podejście młodych ludzi do tych kwestii (Haddouche, Salomone, 2018). Również badania przeprowadzone wśród przedstawicieli pokolenia Z w Polsce dowodza, iż od troski o środowisko często ważniejszy jest rachunek ekonomiczny - motorem oszczędzania energii czy wody jest bardziej dbałość o wysokość prywatnych wydatków niż świadoma postawa ekologiczna. Młodzi ludzie zdają sobie jednak sprawę z tego, że środowisko przyrodnicze warto chronić przede wszystkim w trosce o zdrowie własne, swoich najbliższych oraz przyszłych pokoleń, co można uznać za obiecującą perspektywę (Kwiatek, Skiba, 2017).

\section{METODOLOGIA BADAŃ}

Artykuł jest oparty na wynikach badań empirycznych. Aby zrealizować opisane we wstępie cele, przeprowadzono badania pilotażowe $\mathrm{z}$ wykorzystaniem metody sondażu diagnostycznego i techniki ankietowania. Badania sondażowe z wykorzystaniem techniki ankiety 
bezpośredniej audytoryjnej standaryzowanej, przeprowadzono w grupie 245 młodych osób w okresie od grudnia 2019 r. do stycznia 2020 r. Ankiety były wypełniane przez grupy respondentów zgromadzonych $\mathrm{w}$ tym samym miejscu i czasie. Badania przeprowadzono w Warszawie jako miejscu, które generuje duży popyt turystyczny. W badaniu wzięły udział osoby w przedziale wiekowym 18-25 lat. Respondenci najczęściej mieli 19 lat $(26,1 \%), 20$ lat $(21,2 \%)$ oraz 18 lat $(18,4 \%)$. Najmniej liczną grupę stanowili respondenci w wieku 23 i 26 lat (po 0,82\%). Wśród ankietowanych przeważały kobiety $(62,4 \%)$. Były to na ogół osoby uczące się $(47,7 \%)$ oraz takie, które jednocześnie studiowały i pracowały $(48,2 \%)$.

Ankieta składała się z ośmiu pytań dotyczących omawianego problemu. W kwestionariuszu uwzględniono: - stosunek młodych ludzi do zachowań związanych z ochroną środowiska i do produktów ekologicznych;

- rodzaje i częstotliwość działań podejmowanych na rzecz ochrony środowiska w życiu codziennym;

- znaczenie dla respondenta faktu, że wybrane produkty i proces ich tworzenia są nieszkodliwe dla środowiska;

- skłonność do ponoszenia wyższych kosztów za produkty ekologiczne oraz za nocleg $\mathrm{w}$ obiekcie wdrażającym proekologiczne rozwiązania;

- zachęty, które skłoniłyby do zaangażowania w praktykę proekologiczną obiektu;

- stopień satysfakcji z działań podejmowanych w ramach polityki ekologicznej obiektów noclegowych.

Próbowano także określić, czy badani lepiej oceniliby obiekty, w których wdrażane są rozwiązania wynikające z dbałości o środowisko, i w efekcie chętniej korzystaliby z oferowanych $w$ nich usług. Przeprowadzone badania pozwoliły dokonać interpretacji wyników za pomocą analizy, syntezy i dedukcji.

\section{WYNIKI BADAŃ}

Pierwsze pytanie skierowane do respondentów miało charakter ogólny, wprowadzający w bardziej szczegółową problematykę. Respondenci mieli za zadanie ocenić swój stosunek do zachowań i produktów ekologicznych. $Z$ badań wynika, iż ponad połowa ankietowanych $(59,1 \%)$ stara się przestrzegać zasad ekologii, ale nie zawsze jej się to udaje. Duża grupa respondentów $(19,2 \%)$ uznaje to za ważne, zawsze stara się dbać o środowisko, niemniej jednak są też osoby $(8,9 \%)$, którym ta kwestia jest obojętna. Z kolei 3,7\% badanych chroni przyrodę tylko wtedy, gdy jest to zgodne $z$ ich interesem, $1,2 \%$ zaś uznaje takie działania za stratę czasu. Do tej kwestii nie ustosunkowało się 7,7\% respondentów.

Badania pozwoliły wskazać wdrażane na co dzień przez młodych ludzi zachowania proekologiczne oraz ich częstotliwość. Wyniki przedstawiono w tab. 1.

Najczęstsze działania proekologiczne podejmowane przez młode pokolenie to: zwracanie uwagi na niewyłączone światło, sortowanie śmieci, noszenie własnej torby na zakupy i niekupowanie toreb jednorazowych. Często lub od czasu do czasu młodzież oszczędza energię elektryczną i wodę oraz stara się kupować zdrową żywność. Większość przedstawicieli pokolenia Z korzysta $\mathrm{z}$ toreb biodegradowalnych raz na jakiś czas, ale też duża grupa używa ich zawsze lub często. Ankietowani unikają opakowań z plastiku czasami lub prawie nigdy. Bardzo rzadko oddają butelki do skupu, ponad połowa respondentów nie robi tego w ogóle.

W trakcie dokonywania zakupów bardzo ważne wydaje się zwracanie uwagi na to, czy nabywany produkt ostateczny jest nieszkodliwy dla środowiska i czy jego produkcja spełnia ten wymóg. $Z$ tego powodu ważność kwestii ekologicznych przy zakupie różnych

Tabela 1. Rodzaje i częstotliwość codziennych zachowań proekologicznych wśród osób należących do pokolenia Z

\begin{tabular}{|l|c|c|c|c|c|}
\hline \multirow{2}{*}{ Zachowania } & \multicolumn{5}{c|}{ Liczba odpowiedzi (w \%) } \\
\cline { 2 - 6 } & $\begin{array}{c}\text { Zawsze, } \\
\text { kiedy mogę }\end{array}$ & $\begin{array}{c}\text { Często, } \\
\text { staram się }\end{array}$ & $\begin{array}{c}\text { Od czasu } \\
\text { do czasu }\end{array}$ & $\begin{array}{c}\text { Prawie nigdy, } \\
\text { nigdy }\end{array}$ & $\begin{array}{c}\text { Brak } \\
\text { odpowiedzi }\end{array}$ \\
\hline Sortuję śmieci & 33,06 & 34,70 & 25,71 & 6,12 & 0,41 \\
\hline Oszczędzam wodę, ograniczam jej zużycie & 22,04 & 39,19 & 28,16 & 10,20 & 0,41 \\
\hline $\begin{array}{l}\text { Noszę własną torbę na zakupy, staram się nie } \\
\text { kupować toreb jednorazowego użytku }\end{array}$ & 38,78 & 29,38 & 17,96 & 13,47 & 0,41 \\
\hline Korzystam z toreb biodegradowalnych & 21,22 & 22,86 & 37,96 & 17,55 & 0,41 \\
\hline $\begin{array}{l}\text { Oszczędzam energię elektryczną, ograniczam jej } \\
\text { zużycie }\end{array}$ & 18,37 & 32,65 & 35,10 & 13,47 & 0,41 \\
\hline $\begin{array}{l}\text { Staram się kupować i wykorzystywać zdrową } \\
\text { żywność }\end{array}$ & 24,49 & 38,78 & 30,20 & 6,12 & 0,41 \\
\hline Zwracam uwagę na niewyłączne światło & 50,20 & 30,20 & 15,51 & & 3,68 \\
\hline Oddaję szklane butelki do skupu & 7,76 & 9,79 & 22,04 & 60,00 & 0,41 \\
\hline Unikam opakowań z plastiku & 7,76 & 18,77 & 39,59 & 33,47 & 0,41 \\
\hline
\end{tabular}

Źródło: opracowanie własne. 
produktów oceniano w skali od 1 do 5 , gdzie 1 oznaczało „bez znaczenia”, a 5 - „bardzo duże znaczenie”.

Przy zakupie takich produktów, jak: żywność (63,68\%), soki $(57,15 \%)$, jabłka (51,43\%), energia elektryczna $(50,2 \%)$, respondenci najczęściej przywiązują dużą wagę (oceny 5 i 4) do tego, czy produkt jest nieszkodliwy dla środowiska i czy został stworzony w takich warunkach. Nieco rzadziej pojawia się bardzo silne i silne znaczenie w odpowiedziach respondentów przy takich produktach, jak: samochód (43,26\%), środki czystości (42,86\%), wyjazd turystyczny $(42,44 \%)$, posiłek w restauracji $(39,19 \%)$, nocleg w hotelu (36,73\%). Badani najmniej interesują się szkodliwością dla środowiska, kupując paliwo. Kwestia ta ma bardzo duże i duże znaczenie dla $28,98 \%$ badanych, a dla $31,43 \%$ jest zupełnie nieistotna.

Ankietowani różnie reagowali na pytanie, czy są skłonni płacić więcej za produkty ekologiczne. Zdania respondentów były podzielone, choć zauważalna jest lekka przewaga odpowiedzi twierdzących. Więcej osób wybrało odpowiedź „raczej tak” (36,7\%) niż „raczej nie” (28,57\%) oraz „zdecydowanie tak" (5,7\%) niż „zdecydowanie nie" (4,9\%). Spora grupa respondentów (22\%) nie miała na ten temat zdania, a $2 \%$ ankietowanych nie udzieliło odpowiedzi.

Kolejne pytania dotyczyły stosunku ankietowanych do realizowanej przez obiekty noclegowe polityki proekologicznej. W celu przestrzegania jej zapisów w obiektach noclegowych wdrażane są rozwiązania mające na celu ochronę środowiska, bardzo często związane z ograniczeniami i obniżeniem komfortu klienta. W związku z tym respondenci deklarowali poparcie dla takich propozycji, uznając je za źródło swojego potencjalnego lub rzeczywistego zadowolenia. Młodzi ludzie oceniali w skali od 1 do 7 wdrażane najczęściej rozwiązania, gdzie 1 oznaczała niezadowolenie, a 7 - bardzo dużą satysfakcję z ich wprowadzenia. Aby respondenci mogli wyrazić swój stosunek do rozwiązań proekologicznych w obiektach noclegowych, nie musieli być ich gośćmi lub korzystać z oferowanych tam usług. Wyniki tej części kwestionariusza zaprezentowano w tab. 2.

$\mathrm{Z}$ danych zaprezentowanych $w$ tab. 2 wynika, iż respondenci popierają wiele rozwiązań o charakterze proekologicznym, wprowadzanych $\mathrm{w}$ bazie noclegowej. Analizując rozkład odpowiedzi, w szczególności procentowy udział ocen 6 i 7, można zauważyć, iż badani są najbardziej zadowoleni z czujników ruchu na korytarzach, energooszczędnych źródeł światła, wyposażenia hotelu w panele słoneczne, stosowania kart magnetycznych oraz segregacji odpadów. Niewiele mniejszą grupę satysfakcjonuje stosowanie dozowników na mydło, oferowanie napojów w szklanych butelkach, zastąpienie ręczników papierowych suszarkami do rąk i zamieszczanie $w$ pokojach informacji na temat

Tabela 2. Deklaracja poparcia dla rozwiązań proekologicznych wdrażanych w obiektach noclegowych

\begin{tabular}{|c|c|c|c|c|c|c|c|c|}
\hline \multirow[b]{2}{*}{ Rozwiązanie/działanie proekologiczne } & \multicolumn{8}{|c|}{ Ocena (liczba odpowiedzi w \%) } \\
\hline & 1 & 2 & 3 & 4 & 5 & 6 & 7 & $\begin{array}{c}\text { brak } \\
\text { odpowiedzi }\end{array}$ \\
\hline $\begin{array}{l}\text { Zmiana ręczników i pościeli jedynie na życzenie } \\
\text { gości }\end{array}$ & 13,88 & 9,79 & 11,84 & 12,24 & 14,70 & 8,16 & 25,31 & 4,08 \\
\hline $\begin{array}{l}\text { Stosowanie dozowników na mydło zamiast } \\
\text { mydła jednorazowego }\end{array}$ & 4,08 & 2,04 & 11,84 & 8,57 & 19,59 & 11,02 & 38,78 & 4,08 \\
\hline $\begin{array}{l}\text { Stosowanie kart magnetycznych uruchamiających } \\
\text { oświetlenie w pokojach }\end{array}$ & 3,27 & 3,67 & 9,39 & 11,02 & 17,55 & 12,65 & 38,37 & 4,08 \\
\hline Oferowanie napojów w butelkach zwrotnych & 4,90 & 6,12 & 9,80 & 9,80 & 17,55 & 18,37 & 29,38 & 4,08 \\
\hline $\begin{array}{l}\text { Zamieszczanie w pokojach informacji } \\
\text { o zachowaniach proekologicznych }\end{array}$ & 5,31 & 10,61 & 11,02 & 14,29 & 17,96 & 13,06 & 23,27 & 4,48 \\
\hline Segregowanie odpadów & 4,08 & 5,71 & 6,94 & 11,84 & 16,33 & 13,88 & 36,74 & 4,48 \\
\hline $\begin{array}{l}\text { Zastąpienie ręczników papierowych suszarkami } \\
\text { do rąk }\end{array}$ & 7,35 & 5,71 & 11,43 & 16,33 & 15,92 & 11,84 & 26,94 & 4,48 \\
\hline Stosowanie energooszczędnych źródeł światła & 0,82 & 1,63 & 8,57 & 11,84 & 17,14 & 14,29 & 41,63 & 4,08 \\
\hline Oferowanie żywności ekologicznej & 0,82 & 3,27 & 13,46 & 11,84 & 20,41 & 17,14 & 28,98 & 4,08 \\
\hline Wyposażenie hotelu w panele słoneczne & 2,45 & 2,04 & 8,98 & 11,84 & 18,78 & 10,61 & 41,22 & 4,08 \\
\hline $\begin{array}{l}\text { Czujniki ruchu na korytarzach - automatyczne } \\
\text { wyłączanie zbędnych urządzeń }\end{array}$ & 2,04 & 6,53 & 5,71 & 9,39 & 15,92 & 11,43 & 44,90 & 4,08 \\
\hline Ograniczenia w działaniu klimatyzacji & 7,76 & 6,53 & 15,92 & 17,14 & 21,22 & 16,33 & 11,02 & 4,08 \\
\hline Ograniczenie temperatury i zużycia wody & 9,80 & 12,24 & 13,06 & 15,92 & 17,55 & 11,43 & 15,92 & 4,08 \\
\hline Wydłużenie czasu wykorzystywania pościeli & 17,14 & 10,61 & 14,29 & 15,92 & 17,14 & 11,43 & 9,39 & 4,08 \\
\hline
\end{tabular}

Źródło: opracowanie własne. 
zachowań proekologicznych. Należy zwrócić uwagę na fakt, że przedstawiciele młodego pokolenia są coraz mniej zadowoleni, lub wręcz niezadowoleni z takich rozwiązań, jak: zmiana ręczników i pościeli na życzenie gości, ograniczenie temperatury i zużycia wody oraz działania klimatyzacji.

W związku z tym, iż niezwykle istotne jest włączanie klientów we wdrażanie proekologicznych rozwiązań w obiektach, zapytano respondentów, co zachęciłoby ich do zaangażowania się $\mathrm{w}$ takie inicjatywy. Ankietowani przeważnie $\mathrm{w}$ zamian za podejmowanie działań proekologicznych w hotelu oczekują różnych profitów (zniżka na nocleg $-72,24 \%$, czy na usługi oferowane w obiekcie $-65,71$, gotówka - 38,37\%). Uczestnicy badania w mniejszym stopniu wskazywali na nagrody rzeczowe $-29,39 \%$, czy dodatkowe punkty w programie lojalnościowym - 20,41\%.

Na pytanie, czy przedstawiciele pokolenia Z lepiej oceniliby obiekt noclegowy, w którym wprowadzane są rozwiązania proekologiczne, i w efekcie chętniej zatrzymaliby się tam, największa grupa respondentów (50,61\%) odpowiedziała, że „raczej tak”, zaś niemal $20 \%$ badanych uznało, że „zdecydowanie tak". Jedynie $4,48 \%$ osób biorących udział w badaniu było odmiennego zdania i zadeklarowało odpowiedź "raczej nie”, a zaledwie 0,4\% - „zdecydowanie nie". Część uczestników ankiety $(23,26 \%)$ nie miała zdania na ten temat.

Odpowiedzi na pytanie, czy młodzi ludzie byliby gotowi płacić więcej za nocleg w obiekcie, w którym stosowane są rozwiązania proekologiczne, nie były tak optymistyczne. Zdania respondentów były podzielone. Choć największa grupa badanych, ale już zdecydowanie mniejsza niż w przypadku poprzedniego pytania - 32,65\%, wybrała odpowiedź „,raczej tak”, a 6,5\% - „zdecydowanie tak", to przeciwnego zdania było aż 26,9\% osób, które stwierdziły, że „raczej nie”, oraz 7,34\%, uznających, że „zdecydowanie nie”. Odsetek respondentów, którzy nie potrafili się ustosunkować do tej kwestii, był podobny jak w przypadku poprzedniego pytania $(23,67 \%)$.

\section{PODSUMOWANIE}

Wdrażanie Agendy na rzecz zrównoważonego rozwoju 2030 (Przekształcamy nasz świat..., 2020) i realizowanie jej celu dotyczącego zrównoważonej konsumpcji wymaga zaangażowania konsumentów produktów turystycznych $\mathrm{w}$ działania proekologiczne. Wskazane jest, by turysta jako ekologiczny konsument przejawiał aktywność proekologiczną nie tylko na co dzień we własnym gospodarstwie domowym, ale też $\mathrm{w}$ trakcie podróży turystycznych, $\mathrm{w}$ tym powinien on w istotny sposób wspierać podmioty turystyczne $\mathrm{w}$ realizacji założeń ich polityki związanej z ochroną przyrody. Wybór obiektów noclegowych, w których dba się o środowisko, oraz akceptacja proekologicznych rozwiązań powinny być przejawem wysokiej świadomości ekologicznej, będącej - w szczególności w przypadku młodego pokolenia konsumentów - efektem jej systematycznego kształtowania w ramach formalnej i nieformalnej edukacji.

Wyniki badań zaprezentowane w artykule dostarczają wielu cennych informacji na temat postaw proekologicznych osób należących do pokolenia Z oraz ich stosunku do tego typu działań podejmowanych w obiektach noclegowych. Ukazanie tych danych było głównym celem niniejszego opracowania. Odnośnie do zachowań i wyborów konsumpcyjnych młodzież w większości stara się stosować zasady ekologii - popiera produkty i działania proekologiczne - choć deklaruje, że nie zawsze udaje jej się ich przestrzegać. Wspomniane wyniki badań są potwierdzeniem wcześniejszych ustaleń wskazujących na dbałość młodych ludzi o środowisko i chęć jego ochrony. Podejmowane $\mathrm{w}$ największym stopniu na co dzień działania proekologiczne wynikają jednak z wprowadzonych wymogów prawnych (segregacja śmieci) lub z pobudek ekonomicznych oraz zdrowotnych (niekupowanie toreb jednorazowych, pamiętanie o wyłączaniu światła, oszczędzanie energii i wody, zakup zdrowej żywności). Jest to też zgodne $z$ wcześniejszymi badaniami wskazującymi, iż przesłankę podejmowanych działań stanowi bardziej troska o wydatki aniżeli świadoma postawa ekologiczna.

Młodzież niestety nie jest przyzwyczajona do rezygnacji z produktów w opakowaniach z plastiku oraz oddawania szklanych butelek do skupu. Respondenci w większym stopniu zwracają uwagę na to, czy produkt i jego produkcja są nieszkodliwe dla środowiska, w przypadku robienia zakupów spożywczych niż podczas wyjazdów turystycznych, wyboru noclegu w hotelu czy posiłku w restauracji. Niemniej jednak dla sporej grupy badanych duże znaczenie ma to, czy produkty turystyczne są ekologiczne.

Postmilenialsi $\mathrm{w}$ różnym stopniu aprobują rozwiązania proekologiczne wdrażane $w$ bazie noclegowej. Niektóre elementy polityki na rzecz ochrony środowiska w obiektach noclegowych są popierane i w dużym stopniu akceptowane przez mniej więcej $50 \%$ osób biorących udział w badaniu, niemniej jednak istnieją również takie propozycje (np. wydłużenie czasu wykorzystania pościeli czy zmiana ręczników i pościeli na życzenie gości), które nie spotkały się z pozytywnym odbiorem dużej grupy respondentów. Zdania na temat gotowości do ponoszenia większych kosztów za produkty ekologiczne oraz usługi w obiekcie, w którym dba się o środowisko, są podzielone. Pokolenie Z za swoje zaangażowanie $w$ działalność proekologiczną prowadzoną $w$ hotelu oczekuje też konkretnych korzyści finansowych w postaci zniżek czy gotówki. 
Optymizmem napawa fakt, iż duża grupa młodych ludzi, wiedząc o rozwiązaniach proekologicznych wdrażanych w obiekcie, lepiej go ocenia i jest gotowa zdecydować się na niego. Daje to pozytywną odpowiedź na zadane we wstępie pytanie oraz potwierdza postawioną hipotezę. Polityka ekologiczna i wdrażane w celu realizacji jej zasad działania na rzecz ochrony środowiska mogą być źródłem przewagi przedsiębiorstw świadczących usługi noclegowe. Analizując wyniki badania, należy pamiętać o jego pilotażowym charakterze. Zarówno dobór próby, jak i jej liczebność ograniczają możliwość uogólniania wniosków. Należy jednak podkreślić znaczenie omawianej tematyki i rosnącą rolę zagadnień związanych ze zrównoważonym rozwojem we współczesnym świecie, co z całą pewnością przemawia za kontynuacją badań w tym zakresie.

\section{BIBLIOGRAFIA}

Anderson, K., Sharp, B. (2010). Do growing brands win younger consumers? International Journal of Market Research, 52 (4), 433-441. DOI: https://doi.org/10.2501/S1470785309201387

Baker, M.A., Davis, E.A., Weaver, P.A. (2014). Eco-friendly attitudes, barriers to participation, and differences in behavior at green hotels. Cornell Hospitality Quarterly, 55 (1), 89-99. DOI: https://doi.org/10.1177/1938965513504483

Beccera, M., Santalo, J., Silva, R. (2013). Being belter vs. being different: Differentiation competition and pricing strategies in the Spanish hotel industry. Tourism Management, 34, 71-79. DOI: https://doi.org/10.1016/j.tourman.2012.03.014

Berezan, O., Millar, M., Raab, C. (2014). Sustainable hotel practices and guest satisfaction levels. International Journal of Hospitality \& Tourism Administration, 15, 1-18. DOI: https:// doi.org/10.1080/15256480.2014.872884

Bohdanowicz, P. (2006). Environmental awareness and initiatives in the Swedish and Polish hotel industries - survey results. International Journal of Hospitality Management, 25 (4), 662-668. DOI: https://doi.org/10.1016/j.ijhm.2005.06.006

Borkowska-Niszczota, M. (2011). Rozwiązania proekologiczne jako sposób podnoszenia konkurencyjności podmiotów świadczących usługi hotelarskie. Prace Naukowe Uniwersytetu Ekonomicznego we Wroctawiu, 157, 41-54.

Borkowska-Niszczota, M. (2015). Społeczna odpowiedzialność biznesu turystycznego na rzecz zrównoważonego rozwoju na przykładzie obiektów hotelarskich. Economics and Management, 7 (1), 369-392. DOI: https://doi.org/10.12846/j.em.2015.01.23

Bruska, A. (2016). Zrównoważona konsumpcja. Istota, formy, nabywcy. Logistyka Odzysku, 4 (21), 27-31.

Buffa, F. (2015). Young tourists and sustainability. Profiles, attitudes, and implications for destination strategies. Sustainability, 7 (10), 14042-14062. DOI: https://doi.org/10.3390/su71014042

Burzyński, T., Abram, M. (red.) (2011). Ekologia w turystyce jako tendencja rozwoju gospodarki XXI wieku. Kraków: Instytut Turystyki w Krakowie.

Chan, E.S.W., Hawkins, R. (2010). Attitude towards EMSs in an international hotel: An exploratory case study. International Journal of Hospitality Management, 29 (4), 641-651. DOI: https:// doi.org/10.1016/j.ijhm.2009.12.002

Chen, M.F, Tung, P.J. (2014). Developing an extended Theory of Planned Behavior model to predict consumers' intention to visit green hotels. International Journal of Hospitality Management, 36, 221-230. DOI: https://doi.org/10.1016/j.ijhm.2013.09.006

D'Souza, C., Taghian, M. (2005). Green advertising effects on attitude and choice of advertising themes. Asian Pacific Journal of Marketing and Logistics, 17 (3), 51-66. DOI: https:// doi.org/10.1108/13555850510672386

Desai, S.P., Lele, V. (2017). Correlating Internet, social networks and workplace - a case of generation $\mathrm{Z}$ students. Journal of Commerce \& Management Thought, 8 (4), 802-815. DOI: https:// doi.org/10.5958/0976-478.X.2017.00050.7

Edgell, D. (2006). Managing sustainable tourism. A legacy for the future. Nowy Jork: Harworth Hospitality Press.

Ekogeneracja Z (2020). Pobrane z: https://noizz.pl/eko-generacja-z/ xdjgl7t (20.01.2020).

Erdogan, N., Baris, E. (2007). Environmental protection programs and conservation practices of hotels in Ankara, Turkey. Tourism Management, 28, 604-614. DOI: https://doi.org/10.1016/j. tourman.2006.07.003

Evans, D. (2011). Thrifty, green or frugal: Reflections on sustainable consumption in a changing economic climate. Geoforum, 42 (5), 50-557. DOI: https://doi.org/10.1016/j.geoforum.2011.03.008

Gao, Y.L., Mattila, A.S. (2014). Improving consumer satisfaction in green hotels: The roles of perceived warmth, perceived competence, and CSR motive. International Journal of Hospitality Management, 42, 20-31. DOI: https://doi.org/10.1016/j. ijhm.2014.06.003

Ge, H., Chen, S., Chen, Y. (2018). International alliance of green hotels to reach sustainable competitive advantage. Sustainability, 10 (2), 1-15. DOI: https://doi.org/10.3390/su10020573

Gil, M., Jimenez, J.B., Lorente, J.J. (2001). An analysis of environmental management, organizational context and performance of Spanish hotels. Omega, 29 (6), 457-471. DOI: https://doi. org/10.1016/S0305-0483(01)00033-0

Haddouche, H., Salomone, Ch. (2018). Generation Z and the tourist experience: Tourist stories and use of social networks. Journal of Tourism Futures, 4 (1), 69-79, DOI: https://doi. org/10.1108/JTF-12-2017-0059

Hamed, H.M. (2017). Marketing destinations to millennials: Examining the compatibility between the destination marketing organization website and the millennial tourist prospects. Journal of Tourism and Recreation, 3 (1), 1-20. DOI: http://dx.doi. org/10.12735/jotr.v3n1p01

Han, H., Hsu, L.-T., Lee, J.-S. (2009). Empirical investigation of the roles of attitudes toward green behaviors, overall image, gender, and age in hotel customers' eco-friendly decision-making process. International Journal of Hospitality Management, 28 (4), 519-528. DOI: https://doi.org/10.1016/j.ijhm.2009.02.004

Han, H., Hsu, L.-T.J., Lee, J.-S., Sheu, C. (2011). Are lodging customers ready to go green? An examination of attitudes, demographic, and eco-friendly intentions. International Journal of Hospitality Management, 30 (2), 345-355. DOI: https://doi. org/10.1016/j.ijhm.2010.07.008

Han, H., Kim, W., Kiatkawsin, K. (2017). Emerging youth tourism: Fostering young travelers' conservation intentions. Journal of Travel \& Tourism Marketing, 34 (7), 905-918. DOI: https://doi. org/10.1080/10548408.2016.1261758

Han, X., Chan, K. (2013). Perception of green hotels among tourists in Hong Kong: An exploratory study. Services Marketing Quarterly, 34 (4), 339-352. DOI: https://doi.org/10.1080/15332 969.2013.827069

Ip, C., Lee, H.A., Law, R. (2012). Profiling the users of travel websites for planning and online experience sharing. Journal of Hospitality \& Tourism Research, 36 (3), 418-426. DOI: https:// doi.org/10.1177/1096348010388663

Kang, K., Stein, L., Heo, C., Lee, S. (2012), Consumers' willingness to pay for green initiatives of the hotel industry. International 
Journal of Hospitality Management, 31 (2), 564-572. DOI: https:// doi.org/10.1016/j.ijhm.2011.08.001

Kapera, I., Wszendybył-Skulska, E. (2017). Działania proekologiczne w ocenie gości hoteli. Turyzm/Tourism, 27 (2), 59-64. DOI: https://doi.org/10.18778/0867-5856.27.2.05

Kasim, A. (2004). BESR in the hotel sector: A look at tourists' propensity towards environment. International Journal of Hospitality and Tourism Administration, 5 (2), 61-83. DOI: https:// doi.org/10.1300/J149v05n02_04

Kelly, J., Haider, W., Williams, P.W., Englund, K. (2007). Stated preferences of tourists for ecoefficient destination planning options. Tourism Management, 28 (2), 377-390. DOI: https:// doi.org/10.1016/j.tourman.2006.04.015

Kostakis, I., Sardianou, E. (2012). Which factors affect the willingness of tourists to pay for renewable energy? Renewable Energy, 38, 169-172. DOI: https://doi.org/10.1016/j.renene.2011.07.022

Kryk, B. (2011). Konsumpcja zrównoważona a proekologiczne style życia. Studies \& Proceedings of Polish Association for Knowledge Management, 51, 206-218.

Kwiatek, A., Skiba, M. (2017). Świadomość ekologiczna młodych ludzi, Zeszyty Naukowe Politechniki Częstochowskiej. Zarzadzanie, 28 (2), 127-136. DOI: https://doi.org/10.17512/znpcz.2017.4.2.10

Lazányi, K., Bilan, Y. (2017). Generation Z on the labour market - do they trust others within their workplace? Polish Journal of Management Studies, 16 (1), 78-93. DOI: https://doi. org/10.17512/pjms.2017.16.1.07

Lee, J., Hsu, L., Han, H., Kim, Y. (2010). Understanding how consumers view green hotels: How a hotel's green image can influence behavioral intentions. Journal of Sustainable Tourism, 18 (7), 901-914. DOI: https://doi.org/10.1080/09669581003777747

Liang, H. (2013). Research on the core competitive power elements evaluation system of green hotel. Journal of Economic Development, Environment and People, 2 (4), 38-47. DOI: https:// doi.org/10.26458/jedep.v2i4.38

Lorek, S., Fuchs, D. (2013). Strong sustainable consumption governance - precondition for a degrowth path? Journal of Cleaner Production, 38, 36-43. DOI: https://doi.org/10.1016/j. jclepro.2011.08.008

Lorek, S., Spangenberg, J.H. (2014). Sustainable consumption within a sustainable economy - beyond green growth and green economies. Journal of Cleaner Production, 63, 33-44. DOI: https://doi.org/10.1016/j.jclepro.2013.08.045

Manaktola, K., Jauhari, V. (2007). Exploring consumer atti-tude and behaviour towards green practices in the lodging industry in India. International Journal of Contemporary Hospitality Management, 19 (5), 364-377. DOI: https://doi. org/10.1108/09596110710757534

Millar, M., Baloglu, S. (2011). Travelers' most preferred green attributes for a hotel room. Cornell Hospitality Quarterly, 52 (3), 302-311. DOI: https://doi.org/10.1177/1938965511409031

Millar, M., Mayer, K., Baloglu, S., (2012). Importance of green hotel attributes to business and leisure travelers. Journal of Hospitality Marketing and Management, 21 (4), 395-413. DOI: https://doi.org/10.1080/19368623.2012.624294

Mousavi, S.A., Hoşkara, E., Woosnam, K.M. (2017). Developing a model for sustainable hotels in Northern Cyprus. Sustainability, 9 (11), 1-23. DOI: https://doi.org/10.3390/ su9112101

Nemec Rudež, H., Vodeb, K. (2015). Students' use of social media during the travel process. Tourism and Hospitality Management, 21 (2), 179-190. DOI: https://doi.org/10.20867/ thm.21.2.5

Nowacki, M., Awedyk, M., Kowalczyk-Anioł, J., Królikowska, K., Pstrocka-Rak, M., Rak, G. (2017). Strategie rozwoju tu- rystyki w Polsce w kontekście zrównoważonego rozwoju. W: Prace Naukowe Uniwersytetu Ekonomicznego we Wrocławiu. Gospodarka turystyczna w regionie. Przedsiębiorstwo. Samorzad. Wspótpraca. T. 473 (s. 381-389). Wrocław: Wydawnictwo Uniwersytetu Ekonomicznego we Wrocławiu. DOI: https:// doi.org/10.15611/pn.2017.473.35

Opris, I., Cenusa, V.-E. (2017). Subject-spotting experimental method for gen Z. TEM Journal, 6 (4), 683-692. DOI: https:// doi.org/10.18421/TEM64-06

Pawłowski, J. (2016). Eco-rating of hotels as a response to consumers' requirements. Research Papers of Wroclaw University of Economics, 437, 328-337. DOI: https://doi.org/10.15611/ pn.2016.437.32

Prochorowicz, M. (2015). Activity of hotel facilities towards the environmental protection. Europa Regionum, 23, 211-222. DOI: https://doi.org/10.18276/er.2015.23-17

Przekształcamy nasz świat: Agenda na rzecz zrównoważonego rozwoju 2030 (2020). Rezolucja Zgromadzenia Ogólnego ONZ A/ RES/70/1, 25 września 2015. Pobrane z: http://www.gov.pl/ web/rpzwoj/agenda-2030 (20.01.2020)

Richards, G. (2016). The economic impact of youth travel. W: UNWTO, Global report on the power of youth travel. T. 13 (s. 10-13). Madryt: AM Reports, UNWTO.

Robinot, E., Giannelloni, J.L. (2010). Do hotels' „green” attributes contribute to customer satisfaction? Journal of Services Marketing, 24 (2), 157-169. DOI: https://doi. org/10.1108/08876041011031127

da Rosa, F.S., Silva, L.C. (2017). Environmental sustainability in hotels, theoretical and methodological contribution. Brazilian Journal of Tourism Research, 11 (1), 39-60. DOI: https://doi. org/10.7784/rbtur.v11i1.1161

Ryan, V. (2002). Equity management, power sharing and sustainability issues of the 'new tourism'. Tourism Management, 23 (1), 17-26. DOI: https://doi.org/10.1016/S0261-5177(01)00064-4

Ryszawska-Grzeszczak, B. (2007). Ekologiczny wymiar konsumpcji żywności. Ekonomia i Środowisko, 1 (31), 150-164.

Sauthgate, D. (2017). The emergence of generation $\mathrm{Z}$ and its impact in advertising. Long-term implications for media planning and creative development. Journal of Advertising Research, 52 (2), 227-235. DOI: https://doi.org/10.2501/ JAR-2017-028

Sidali, K., Huber, D., Schamel, G. (2017). Long-term sustainable development of tourism in South Tyrol: An analysis of tourists' perception. Sustainability, 9 (10/1791). DOI: https://doi. org/10.3390/su9101791

Tzschentke, N., Kirk, D., Lynch, P.A. (2004). Reasons for going green in serviced accommodation establishments. International Journal of Contemporary Hospitality Management, 16 (2), 116-124. DOI: https://doi.org/10.1108/09596110410520007

UNWTO (2017). Sustainable development. Pobrane z: https://www. unwto.org/sustainable-development (20.01.2020).

Vallone, D., Smith, A., Kenney, T., Greenberg, M., Hair, E., Cantrell, J., Rath, J., Koval, R. (2016). Agents of social change: A model for targeting and engaging generation $\mathrm{Z}$ across platforms. How a nonprofit rebuilt an advertising campaign to curb smoking by teens and young adults. Journal of Advertising Research, 56 (4), 414-425. DOI: https://doi. org/10.2501/JAR-2016-046

Artykuł wpłyną: 6 maja $2020 \mathrm{r}$

Zaakceptowano do druku: 23 października $2020 \mathrm{r}$. 